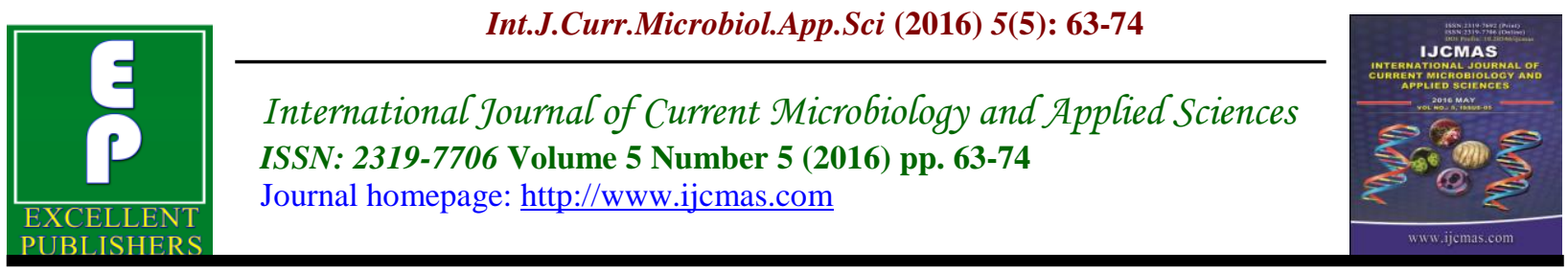

Original Research Article

http://dx.doi.org/10.20546/ijcmas.2016.505.007

\title{
Antagonism Mechanism of Fungal Contamination Animal Feed using Phylloplane Yeasts Isolated from the Bintaro Plant (Cerbera manghas) Bekasi in Java, Indonesia
}

\author{
Dalia Sukmawati* \\ Department of Biology, Faculty of Mathematics and Natural Sciences, Universitas Negeri \\ Jakarta, Kampus B, Pemuda Street No. 10 Rawamangun, Indonesia \\ *Corresponding author
}

\section{A B S T R A C T}

Keywords

Animal feed, Antagonism, Yeast, Molds.

\section{Article Info}

Accepted:

06 April 2016

Available Online:

10 May 2016
Cerbera manghas has many qualities, the leaves have bioactive constituents of insecticides, cosmetics, pesticides, medicinal plants, and antifungal activities. We investigated the diversity yeasts species associated with leaves of $C$. manghans, which is prerequisite to understand the phylloplane yeasts and their antagonistic abilities against molds from chicken feed. Based on the on similarity of colony morphology, three representative molds isolates were selected and identified. Two representative molds are capable of damage of chicken feed, are genus Aspergillus, and Penicillium. A total of 28 yeasts isolates were obtained. The yeasts were able to inhibit growth and sporulation of molds (21 isolate yeasts inhibit Aspergillus; 10 isolate yeasts inhibit Penicillium). Two antagonistic yeasts were able to inhibit growth and sporulation of molds with high zone were code T1.3.5 and T4.5.3.R.The results showed yeasts from phylloplane Bintaro can be used as agents of antagonism in the ability to inhibit mold contaminant origin animal feeds.

\section{Introduction}

Cerbera manghansis plants can grow in the tropical Indo-Pacific region from Seychelles to French Polynesia including Indonesia. Natural habitat is coastal and mangrove forests (mangroves). Cerbera manghansis known by several vernacular names, such as Bintaro, Blind Rhino, Mangga Sea, Wood Octopus, Kanyeri White (Bali), Bilutasi (NTT), Wabo (Ambon), Goro - Goro Guwae (Ternate), Madangkapo (Minangkabau), Bintan (Malay), Lambuto (Makassar), Goro - Goro (Manado ) (Utami, 2010).
Cerbera manghans utilization for the people of Indonesia is used as an ornamental plant, urban greening, raw materials handicraft, botanical pesticides, and medicinal plants. (Utami, 2010). In traditionally C. manghans leaves used as laxatives, emetics, anti rheumatism, sedative, anti - nociceptive, toxic activity in the central nervous system (Ahmed et al., 2008).

Numerous studies have highlighted about potential aspects of $C$. manghans in particular field of health and the safety of 
food. Sa'diyah et al. (1995) reported $C$. manghans contains several compounds are secondary metabolites, such as saponins, polyphenols, terpenoids, and alkaloids. Compound C. manghans are polar because it contains nitrogen and compounds the phenol-soluble polar solvents and semipolar. The seeds of the Bintaro contain cerberin compounds that have the potential to Carcinogenicity (Cheenpracha et al., 2004; Liu et al., 2008).

Research of C. manghas only regarding the utilization of plant extracts. Kariba, 2001 reported of methanol extract of leaves of Schizozygia coffaeoides (Apocynaceae) has been investigated as a fungistatic against Trichophyton mentagrophytes, Microsporum gypseum, Cladosporium cucumerinum, and Candida albicans. Murniana (2011) reported the chemical compounds from the seeds of Cerbera odollam which is one genus with $C$. manghas for antifungal activity against test the fungus $C$. albicans. However, there no report on isolation of yeasts from C.manghas and there is no information on the bioactive compounds and potential antagonism of this microorganism.

The surface of the leaf (phylloplane) is habitat for yeast. The existence of phylloplane yeasts on can get carried away by soil particles and other particles from the air (Watkinson, 1995), and are carried by insects from one plant to another plant (Spencer \&Spencer, 1997).

Some reports about the epiphyte diversity of yeasts derived from leaves, among others, the following: Sukmawati et al. (2015) reported the phylloplane yeasts isolated from the leaves of Broussonetia papyrifera from Bandung, Garut, Trowulan and produced 17 genera and 32 species of yeasts is composed of 11 genera (18 species) of the phylum Ascomycota and 6 genera (14 species) of the phylum Basidiomycota. Sjamsuridzal (2007) to isolate and identify the phylloplane yeasts of plants in Cikurutug, Cikaniki and mount Halimun National Park of Mount Kendeng Ciujung, West Java. There has been no report of research on the phylloplane yeasts from C.manghas.

Mold is one of the microorganisms that can cause contamination (Widhiastuti, 2006). Contamination can occur in a variety of organic substrates. One of the contaminants that occur are on cattle feed. Handayani \& Sulistyo (2000) reported the fungus Aspergillus spp., Cladosporium spp., Absidia spp., Montha spp., Mucor spp., Moniliella spp., and Rhizopus spp.a wellknown contaminate feed on farm poultryand is the main organism responsible for the production of mycotoxin.Mycotoxins are known to be produced by toxigenic fungi, especially under suitable culture conditions.

The effect of contamination pathogen fungi from livestock feed is mycotoxin. Mycotoxin can show a variety of biological effects on chicken such as a decrease in food intake (Merril et al., 2001 in Ahmad, 2009), decrease in immune response (Maruanovic et al., 1991), diminution lymphoid organs, especially the thymus (Tabbu, 2002), a decrease in the efficiency of breeding and neurotoxic (Pestka, 2007 in Ahmad, 2009) as well as cause the disruption of productivity (D'Mello \&Macdonald, 1998). It can cause harm to the chicken food. Recently breeders used use antibiotics for reduce contamination of pathogen molds. However excessive use of antibiotics can lead to declining health in humans.

Therefore, it is necessary alternative mold prevention more effective, does not induce resistance, and safe for human health and the environment. One of the ways that can be 
done is by utilizing yeasts which have the ability of antagonistic (Druvefors, 2004). The ability of yeast was produce a barrier to the growth of other microorganisms (Madigan et al., 2012). In this study, we isolated yeast indigenus Indonesia from Bintaro (C.manghas) which has potential as an agent that can inhibit the growth of mold (Aspergillus sp. and Penicillium sp.) from chicken feed.

\section{Materials and Methods}

\section{Sample and Sampling Location}

Samples of fresh leaves of C.manghas were retrieved from old plants in Bekasi West Java. A total sample of leaves used amounted to 16 leaves. Leaf samples were obtained from four plants of each plant in Bintaro, take 4 strands of leaves.

\section{Isolation of Yeast Isolates}

Isolation of yeasts from the fresh leaves of C. manghas using the method of washing method based on Sjamsuridzal et al. (2013). The leaves are weighed $(1 \mathrm{~g})$, cut into pieces and became part of the minor. Foliage washed with sterile $25 \mathrm{ml}$ akuades (in the conical tube $50 \mathrm{ml}$ ) and vortex for 10 minutes.

Washed pieces of leaves were placed directly onto isolation colloidal chitin medium $(1 \%)$ containing $1 \%$ colloidal

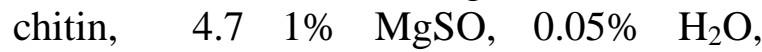
$0.1 \% \mathrm{KH}_{2} \mathrm{PO}_{4}, 0.05 \%$ yeast extract, and $2 \%$ agar, in 1 liter akuades and added with 0.05 \%tetracycline after sterilization. After that $0.1 \mathrm{ml}$ suspension leaf leaching results $C$. manghas was inoculated directly onto $1 \%$ colloidal chitin agar medium in three replicates. Plates were incubated at room temperature $\left(27-28^{\circ} \mathrm{C}\right)$, and after three days all single colonies were picked up using sterile toothpicks and placed into new plates to create colony libraries. The representative colonies of each morphological type were purified at least two times on yeast malt extract agar (YMA), maintained on potato dextrose agar (PDA) slants, and stored at $20^{\circ} \mathrm{C}$. The cultures from this study were deposited in the Jakarta State University Culture Collection (UNJCC), Department of biology, Faculty of mathematics and natural sciences, State University of Jakarta.

\section{Isolation of Molds Isolates from Feed Chicken}

Feed chicken samples taken at a chicken farm villages of Bekasi, West Java. Sampling technique based on Shareef (2010) by the method of purposive sampling. Samples taken from two of the plot i.e. the feed shed and chicken coop. On each plot consists of 5 subplots.

Isolation of molds isolate from feed chicken samples using the method of dilution plating by Labuda et al., 2006). The feed chicken samples are weighed $(1 \mathrm{~g})$, put into sterile water $(9 \mathrm{ml})$ then make dilution at $10^{-4}, 10^{-5}$ and $10^{-6}$.After that $0.1 \mathrm{ml}$ suspension was inoculated directly onto PDA medium. And after seven days all single colonies were picked up using sterile toothpicks and placed into new plates to create colony libraries at a temperature of $25^{\circ} \mathrm{C}-30^{\circ} \mathrm{C}$.

\section{Antagonism Test Method}

Antagonism test method that is carried out for early screening method based on point, by Csutak, et al. (1995). This antagonism test using yeast isolate from the fresh leaves of $C$. manghans and molds isolate (Aspergillus sp. and Penicillium sp.) from animal feed. Antagonism test using PDA medium. One medium PDA is is divided into four quadrants. After that yeast isolate (48 $\mathrm{h}$ incubation) scratch on the medium. On the central part of medium was inoculation with mold ( $5 \mathrm{~d}$ incubation). The 
ability of yeasts in inhibiting the growth of mold is determined by reduced growth of mycelium on the mold. Incubation is done during 5 days at a temperature of $26-28{ }^{\circ} \mathrm{C}$.

\section{Results and Discussion}

\section{Isolation of Yeasts from Fresh Leaves of C. manghans}

Thirty six yeast and mold isolates (20 yeast and 16 mold isolates) have been obtained (Table 1). Yeast isolates obtained have a difference in colors and textures. The colors and textures of yeast colonies, and their percentages are as follows: mucoid orange (25\%), butyrous white $(30 \%)$, butyrous blackish $(20 \%)$, butyrous cream $(20 \%)$, and butyrous orange (1\%)on YMA after 3 days incubation at room temperature $\left(27-28^{\circ} \mathrm{C}\right)$ (Table 2).

In this study we found variety of texture and colors of yeast isolates. It indicates that the surface of the leaves is a proper habitat for the growth of yeast. Yeast can grow on the surface of the leaves have a characteristic morphology dominated with texture butyrous $(75 \%)$ and with variety pigment. Fonseca and Inacio (2006) reported the yeast isolates from phylloplane that have been dominated by the pigments such as beige, orange, blackish, cream and pink.Dufosse (2006) reported the yeasts can produce pigments, among others: pink (astaxanthin), black (melanin), orange (torularhodin) and red ( $\beta$ carotene). The pigment on the yeasts serve to protect yeasts of unfavorable environmental conditions such as light intensity and ultraviolet radiation (Luciana et al., 1998).

\section{Isolation of Molds from Animal Feed Chicken}

Macroscopic and Microscopic
Observation of Mold Isolates

In this study we were obtained two genera of mold from cattle feed in Bekasi, West Java. Genera were Penicillium and Aspergillus. Observations of macroscopic and microscopic morphology have been done in the medium Malt Extract Agar (MEA) and incubated at a temperature of $27-28{ }^{\circ} \mathrm{C}$.

Observations colony of the genus Aspergillus sp. at the age of five days in medium MEA show cedar green with the edge of the ivory, the texture, the granules have exudate drops, growing zone, zoning and radial furrow, the color behind the colony of brown. On microscopic observations, the genus Aspergillus sp. This genus contained conidiophore, vesicles, and head of conidia.

Colony morphology of the genus Aspergillus sp. in accordance with the description by Klich (2002), namely, molds of the genus Aspergillus at 7 days in medium Malt Extract Agar (MEA) has a granular texture, mycelium is white, head of the conidia of the old Brown to black, and greyish-yellow colonies rather than too colorless. Based on observations colonies of Aspergillussp. microscopically: the hypha has septa, conidiophore on the ends rounded form vesicles, metula and phialid (Fig.1).

Observations colony of the genus Penicillium sp. shows the colored mold colony night green with colored edges white, texture granule, has a growing zone, exudate drop and zone, has no radial furrow, the color behind the colony brunt ochre. On microscopic observations, a colony of Penicillium sp. has a characteristic that is conidiophore on the ends of branches, has the metula and phialid as a place of conidia which vary from round, semi rounded and ovoid (Fig. 2).

Colony morphology in the genus Penicillium sp. in accordance with the description according to Gams, et al. (1987) 
a colony of Penicillium sp. is usually white, sometimes green, most have conidiophore. Single Conidiophore (mononematus) or compound (synematous), consisting of a single trunk dividing some of the phialid (simple/monoverticillata). Phialid is the structure that sustains conidia, cylindrical drier basal narrowing in neck, or lanceolate (the most basal part embedded at the end of the tip). Conidia long chain-shaped, elliptical, globular, transparent, or greenish, with smooth or wavy walls (Gandjar et al. 1984).

\section{Screening Antagonism of Original Phylloplane Yeast Isolates $C$. manghas with Aspergillus sp. and Penicillium sp}

Screening antagonism of original phylloplane yeast isolates $C$. manghas with Aspergillus sp. and Penicillium sp. using PDA medium incubation 3 days at a temperature of 27-28 ${ }^{\circ} \mathrm{C}$. The results showed of the antagonism of 20 original yeast isolates of $C$. manghas against mold, Aspergillus sp. and Penicillium sp. showed positive results. A total $100 \%$ isolate yeasts capable of inhibiting the mold Aspergillus sp. with average inhibition (0.85--6.31) mm and $40 \%$ isolate yeasts are able to inhibit mold Penicillium spwith average inhibition (0.79--6.91) (Fig 3-4). The distance of the largest shown by the inhibition of yeast isolates code $\mathrm{T}$ 1.3.5 with a diameter inhibition of $6.31 \mathrm{~mm}$ on the mold Aspergillus sp. and yeast isolates code $\mathrm{T}$ 4.5.3. R too Penicillium sp. mold with diameter inhibition $6.91 \mathrm{~mm}$ (Table 3-4).

We found that the phylloplane yeast isolates of $C$. manghas were be potential antagonism mechanism inhibited mold contamination especially Aspergillus sp. and Penicillium sp. Interaction antagonism between yeast isolates against Aspergillus sp. and Penicillium sp.thought to be competition of nutrient and living space. We suggest too this antagonism mechanism involves chitinase enzyme. This yeast isolates were produced chitinase enzyme due to we used colloidal medium (1\%) for isolation. The yeast isolates were can growed on colloidal chitin medium supposedly had the ability to produce the chitinase enzyme. Chitinase enzyme on yeast extracellular enzymes is to acquire nutrition and parasitism (Patil et al. 2000). Yeast has the ability of antagonistic towards pathogenic mold growth through the mechanism of competition against space and nutrients on their substrates. The inherent yeasts hypha mold then secrete enzymes degradation cell wall mold, i.e. chitinase enzyme (Ge et al., 2010). Yeast species can produce chitinase, i.e. Saccharomyces cerevisiae (Ahmad, 2007); Metschnikowia fruticola (Banani et al. 2015); Pichia guilliermondii K14 and Bulleromyces albus K7 (Preechasuth et al. 2015).

The results showed yeast isolate from phylloplane of $C$. manghans have activity antagonism. Mechanisms antagonism with mold mycelium growth reduction after grown along with yeasts. Interaction antagonism between yeast origin teak leaves with the mold Aspergillus sp., and Penicillium sp. and thought to be the mechanism of nutrient competition and living space. These result supported with Spadaro (2003) reported testing antagonism between yeast Metschnikowia pulcherrima with different cell number $\left(10^{6}\right.$ until $10^{8}$ $\mathrm{CFU} / \mathrm{ml}$ ) mold against Bacillus cinerea. 
Table.1 Mold and Yeast Isolates Obtained from Leaves of C. manghas using Colloidal Chitin Medium Isolation Agar (1\%) for 3 Days Incubation Temperature 30 ${ }^{\mathrm{C}}$

\begin{tabular}{|c|c|c|c|}
\hline Tree & Code of isolates & Fungi & Observation on the morphology \\
\hline \multirow{9}{*}{1} & T1.1.1 & Mold & Filament, greenish white \\
\hline & $\mathrm{T} 1.3 .1$ & Mold & Filament, white \\
\hline & $\mathrm{T} 1.1 .2$ & Yeast & Butyrous, white \\
\hline & $\mathrm{T} 1.3 .1 .1$ & Yeast & Mucoid, orange \\
\hline & $\mathrm{T} 1.3 .2$ & Yeast & Butyrous, cream \\
\hline & $\mathrm{T} 1.3 .3$ & Yeast & Butyrous, cream \\
\hline & $\mathrm{T} 1.3 .5$ & Yeast & Mucoid, orange \\
\hline & $\mathrm{T} 1.2 .1$ & Yeast & Mucoid, orange \\
\hline & $\mathrm{T} 1.3 .4$ & Yeast & Mucoid, orange \\
\hline \multirow{9}{*}{2} & $\mathrm{~T} 2.1 .1$ & Mold & Filament, white \\
\hline & $\mathrm{T} 2.4 .1$ & Mold & Filament, white \\
\hline & $\mathrm{T} 2.4 .2$ & Mold & Filament, white \\
\hline & $\mathrm{T} 2.2 .1 \mathrm{R}$ & Yeast & Butyrous, white \\
\hline & $\mathrm{T} 2.2 .1$ & Yeast & Butyrous, blackish white \\
\hline & $\mathrm{T} 2.2 .3$ & Yeast & Butyrous, white \\
\hline & T.2.2.2 & Yeast & Butyrous, cream \\
\hline & T.2.3.1R & Yeast & Butyrous, cream \\
\hline & $\mathrm{T} 2.5 .1$ & Yeast & Butyrous, white \\
\hline \multirow{7}{*}{3} & T3.3.1 & Mold & Filament, white \\
\hline & $\mathrm{T} 3.3 .2$ & Mold & Filament, white \\
\hline & $\mathrm{T} 3.5 .1$ & Mold & Filament, white \\
\hline & $\mathrm{T} 3.1 .1$ & Yeast & Butyrous, blackish \\
\hline & $\mathrm{T} 3.1 .2$ & Yeast & Mucoid, orange \\
\hline & T3.1.3 & Yeast & Butyrous, blackish \\
\hline & $\mathrm{T} 3.1 .4$ & Yeast & Butyrous, white \\
\hline \multirow{11}{*}{4} & $\mathrm{~T} 4.1 .1$ & Mold & Filament, white \\
\hline & $\mathrm{T} 4.1 .2$ & Mold & Filament, white \\
\hline & $\mathrm{T} 4.2 .1$ & Mold & Filament, white \\
\hline & $\mathrm{T} 4.2 .2$ & Mold & Filament, white \\
\hline & $\mathrm{T} 4.4 .1$ & Mold & Filament, white \\
\hline & $\mathrm{T} 4.4 .2$ & Mold & Filament, white \\
\hline & $\mathrm{T} 4.5 .1$ & Mold & Filament, white \\
\hline & $\mathrm{T} 4.5 .2$ & Mold & Filament, white \\
\hline & $\mathrm{T} 4.5 .3 \mathrm{R}$ & Yeast & Butyrous, white \\
\hline & $\mathrm{T} 4.5 .1 \mathrm{R}$ & Yeast & Butyrous, orange \\
\hline & $\mathrm{T} 4.2 .2 \mathrm{R}$ & Yeast & Butyrous,blackish \\
\hline
\end{tabular}


Table.2 Morphology Colony of Yeast Isolates Obtained from Leaves of C. manghas using YMA Medium for 3 Days Incubation Temperature $30^{\circ \mathrm{C}}$

\begin{tabular}{ccccccc}
\hline \hline Tree & $\begin{array}{c}\text { Total number } \\
\text { of isolates }\end{array}$ & $\begin{array}{c}\text { Mucoid, } \\
\text { orange }\end{array}$ & $\begin{array}{c}\text { Butyrous, } \\
\text { white }\end{array}$ & $\begin{array}{c}\text { Butyrous, } \\
\text { blackish }\end{array}$ & $\begin{array}{c}\text { Butyrous, } \\
\text { cream }\end{array}$ & $\begin{array}{c}\text { Butyrous, } \\
\text { orange }\end{array}$ \\
\hline \hline 1 & 7 & 4 & 1 & & 2 & \\
2 & 6 & & 3 & 1 & 2 & \\
3 & 4 & 1 & 1 & 2 & & 1 \\
4 & 3 & & 1 & 1 & & $1(5 \%)$ \\
\hline \hline Total & 20 & $5(25 \%)$ & $6(30 \%)$ & $4(20 \%)$ & $4(20 \%)$ & $1(20)$ \\
\hline \hline
\end{tabular}

Table.3 Inhibitation Yeasts Isolates from C. manghans with the Mold Aspergillus sp.on PDA Medium Incubation3 Day at Temperature $27-28^{\circ} \mathrm{C}$

\begin{tabular}{lcccc}
\hline \hline Yeast isolates & $\begin{array}{c}\text { Inhibitation of } \\
\text { yeast isolates } \\
(1)\end{array}$ & $\begin{array}{c}\text { Inhibitation of } \\
\text { yeast isolates } \\
(2)\end{array}$ & $\begin{array}{c}\text { Average of zone } \\
\text { inhibitation }\end{array}$ & $\begin{array}{c}\text { Antagonism } \\
\text { Yeast Vs } \\
\text { Aspergillus }\end{array}$ \\
\hline \hline T1.1.2 & 3.73 & 3.71 & 3.72 & + antagonism \\
T1.2.1 & 5.21 & 5.23 & 5.22 & + antagonism \\
T1.3.1.1 & 6.02 & 6.01 & 6.02 & + antagonism \\
T1.3.2 & 2.55 & 2.57 & 2.56 & + antagonism \\
T1.3.3 & 2.83 & 2.82 & 2.83 & + antagonism \\
T1.3.4 & 0.84 & 0.85 & 0.85 & + antagonism \\
T1.3.5 & $\mathbf{6 . 2 8}$ & $\mathbf{6 . 3 3}$ & $\mathbf{6 . 3 1}$ & + antagonism \\
T2.2.1 & 2.04 & 2.14 & 2.09 & + antagonism \\
T2.2.1.R & 1.57 & 1.55 & 1.56 & + antagonism \\
T2.2.2 & 2.83 & 2.82 & 2.83 & + antagonism \\
T2.2.3 & 4.84 & 4.82 & 4.83 & + antagonism \\
T2.3.1R & 5.11 & 5.12 & 5.12 & + antagonism \\
T2.5.1 & 4.29 & 4.28 & 4.29 & + antagonism \\
T3.1.1 & 1.22 & 1.23 & 1.23 & + antagonism \\
T3.1.2 & 1.62 & 1.63 & 1.63 & + antagonism \\
T3.1.3 & 1.83 & 1.9 & 1.87 & + antagonism \\
T3.1.4 & 5.88 & 5.89 & 5.89 & + antagonism \\
T4.2.2.R & 1.41 & 1.4 & 1.41 & + antagonism \\
T4.5.1.R & 3.32 & 3.31 & 3.32 & + antagonism \\
T4.5.3.R & 3.83 & 3.82 & 3.83 & + antagonism \\
\hline \hline
\end{tabular}


Table.4 Inhibitation Yeasts Isolates from C. manghans with the Mold Penicillium sp.on PDA Medium Incubation3 Day at Temperature $27-28{ }^{\circ} \mathrm{C}$

\begin{tabular}{|c|c|c|c|c|}
\hline Yeast isolates & $\begin{array}{c}\text { Inhibitation of yeast } \\
\text { isolates (1) }\end{array}$ & $\begin{array}{c}\text { Inhibitation of } \\
\text { yeast isolates } \\
(2)\end{array}$ & $\begin{array}{l}\text { Average of } \\
\text { zone } \\
\text { inhibitation }\end{array}$ & $\begin{array}{c}\text { Antagonism } \\
\text { Yeast Vs } \\
\text { Penicillium sp. }\end{array}$ \\
\hline T1.1.2 & 4.22 & 4.32 & 4.27 & + antagonism \\
\hline $\mathrm{T} 1.2 .1$ & - & - & - & - \\
\hline $\mathrm{T} 1.3 .1 .1$ & - & - & - & - \\
\hline $\mathrm{T} 1.3 .2$ & 3.23 & 3.33 & 3.28 & + antagonism \\
\hline $\mathrm{T} 1.3 .3$ & - & - & - & - \\
\hline $\mathrm{T} 1.3 .4$ & - & - & - & - \\
\hline $\mathrm{T} 1.3 .5$ & 1.15 & 1.1 & 1.13 & + antagonism \\
\hline $\mathrm{T} 2.2 .1$ & 1.07 & 1.08 & 1.08 & + antagonism \\
\hline T2.2.1.R & 0.78 & 0.79 & 0.79 & + antagonism \\
\hline $\mathrm{T} 2.2 .2$ & - & - & - & - \\
\hline $\mathrm{T} 2.2 .3$ & 1.4 & 1.42 & 1.41 & + antagonism \\
\hline $\mathrm{T} 2.3 .1 \mathrm{R}$ & - & - & - & - \\
\hline $\mathrm{T} 2.5 .1$ & - & - & - & - \\
\hline T3.1.1 & - & - & - & - \\
\hline T3.1.2 & - & - & - & - \\
\hline T3.1.3 & 4.92 & 4.93 & 4.93 & + antagonism \\
\hline $\mathrm{T} 3.1 .4$ & - & - & - & - \\
\hline $\mathrm{T} 4.2 .2 . \mathrm{R}$ & - & - & - & - \\
\hline $\mathrm{T} 4.5 .1 . \mathrm{R}$ & - & - & - & - \\
\hline T4.5.3.R & 6.92 & 6.89 & 6.91 & + antagonism \\
\hline
\end{tabular}

Fig.1 Observations Colony of Mold Aspergillus sp. in medium MEA was 5 Days at a Temperature of $27-28^{\circ} \mathrm{C}$

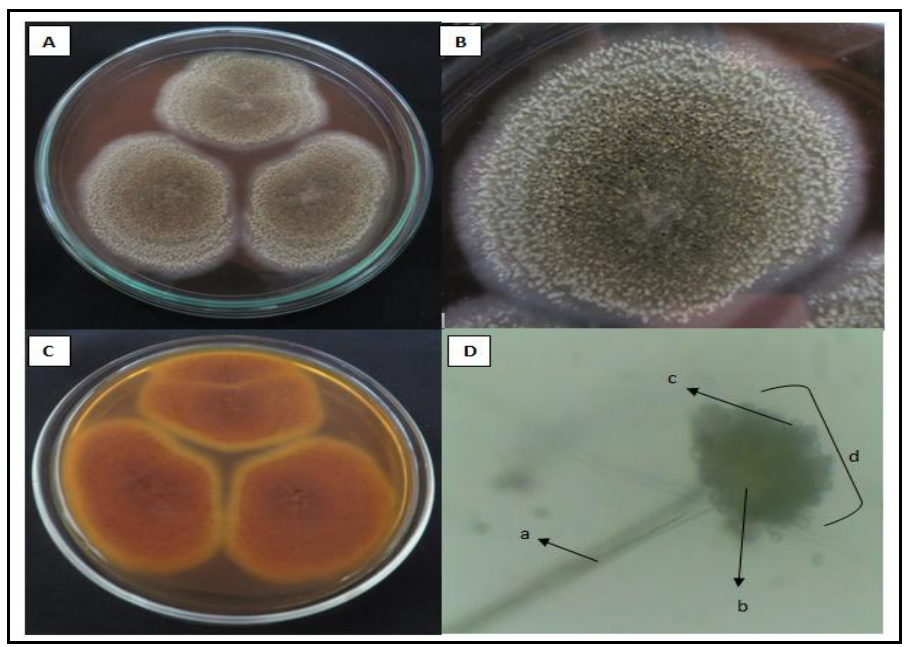

(A). Colonies of mold (B). Macroscopic and microscopic molds, (C). Mold colonies, (D) the microscopic mold magnification $1000 \mathrm{x}$ (a conidiophore, $b$ conidia, $c$ vesicles, $d$ head conidia) 
Fig.2 Colonies of Mold Observations Penicillium sp. in Medium MEA was 5 Days at a Temperature of $27-28^{\circ} \mathrm{C}$

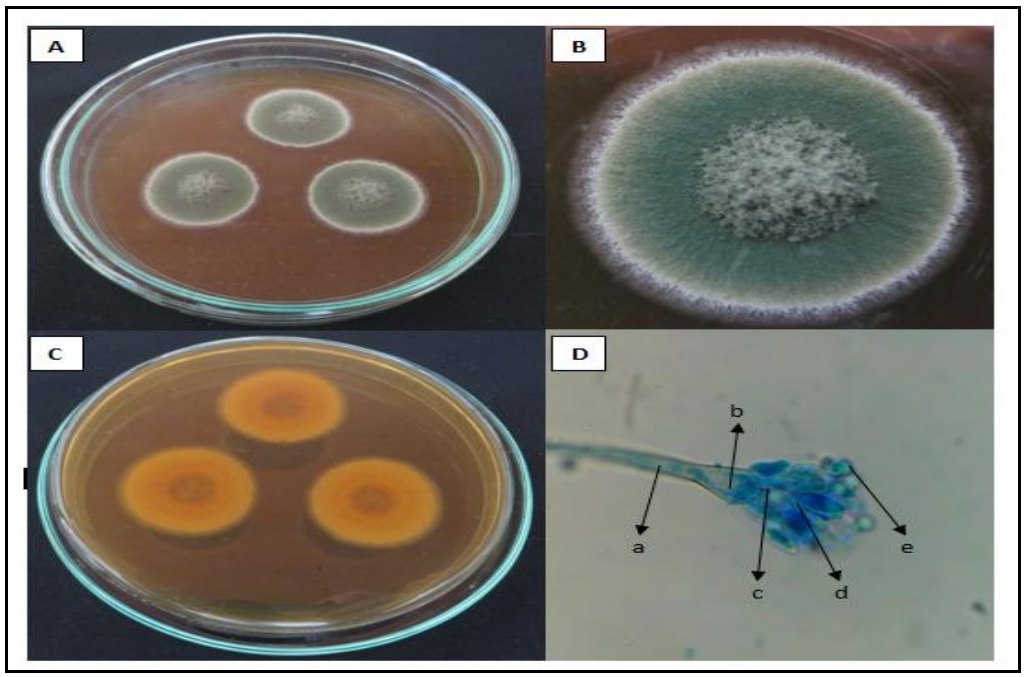

(A). Colonies of mold (B). Macroscopic and microscopic molds, (C). Mold colonies, (D) the microscopic mold magnification $1000 \times$ (a conidiophore, $b$ vesicle, $c$ metula, $d$ phialid, and econidia)

Fig.3 Testing of Antagonism Phylloplane Yeasts Isolates from C. manghans with the Mold Aspergillus sp. on PDA Medium Incubation3 Day at Temperature27-28 ${ }^{\circ} \mathrm{C}$

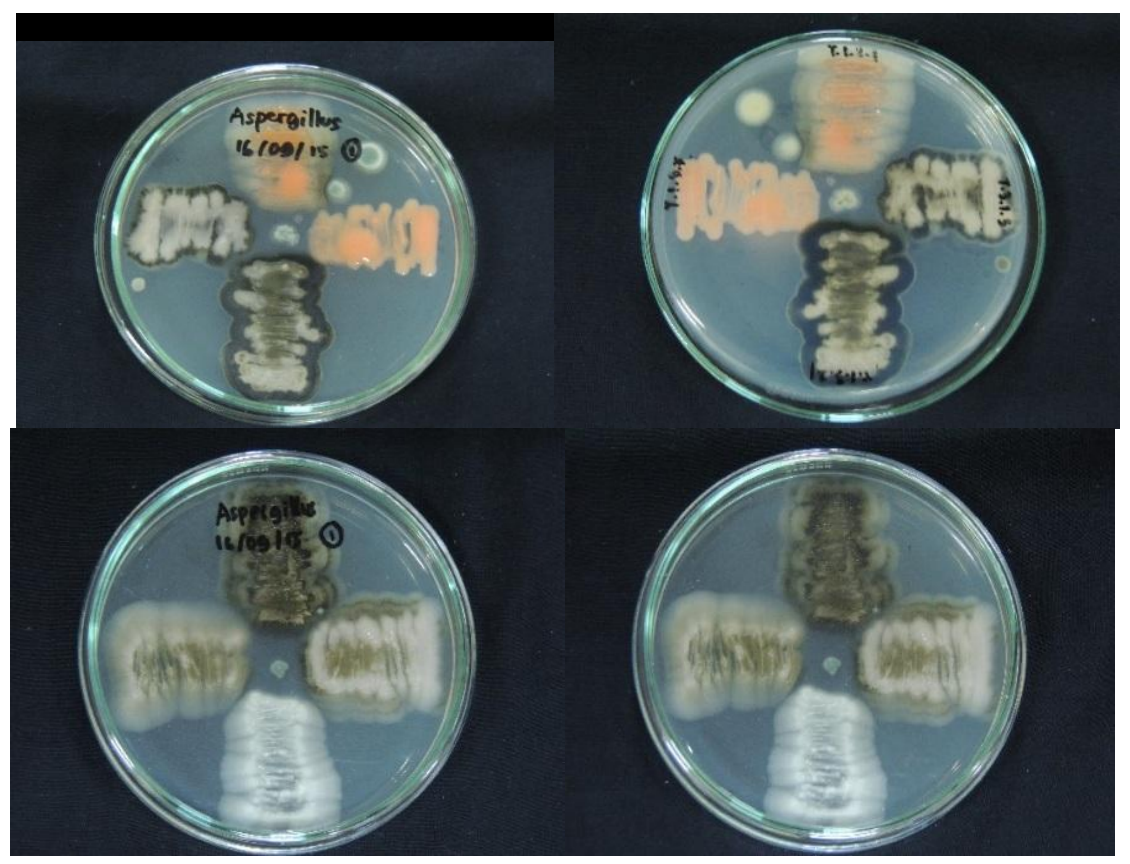


Fig.4 Testing of Antagonism Phylloplane Yeasts Isolates from C. manghans with the Mold Penicillium sp. on PDA Medium Incubation3 Day at Temperature 27-28 C
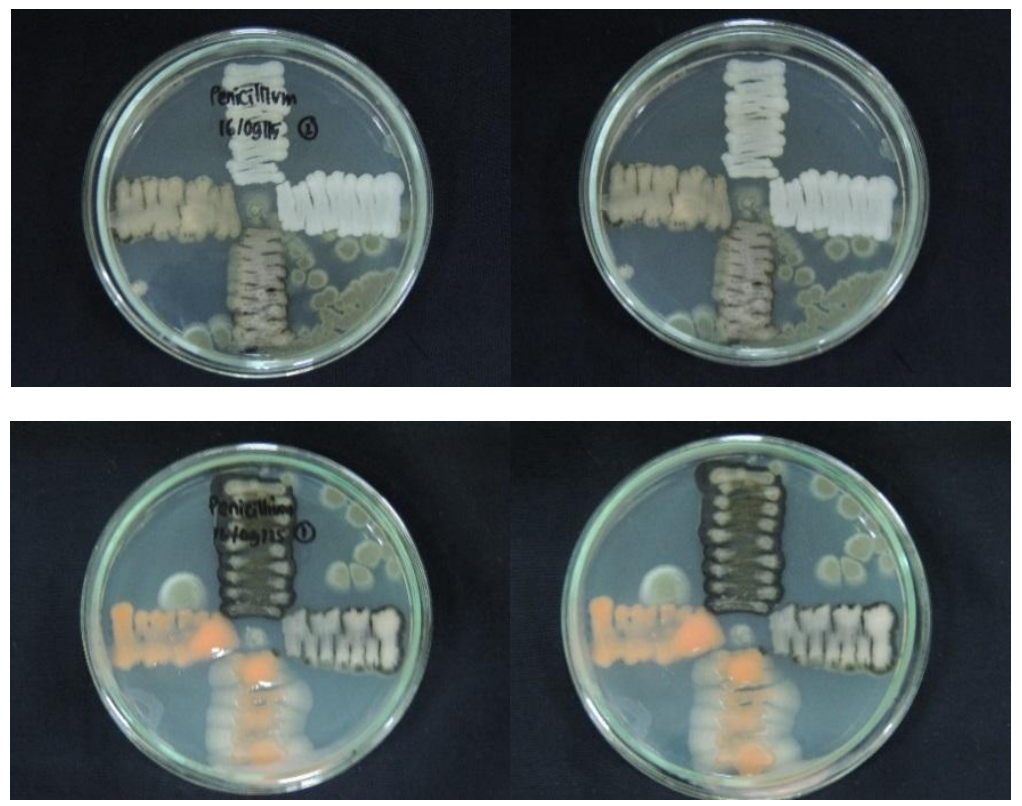

Metschnikowia pulcherrima with cell number $10^{8} \mathrm{CFU} / \mathrm{ml}$ was capable inhibiting the growth of $B$. cinerea mold better than $M$. pulcherrima with cell number $10^{6} \mathrm{CFU} / \mathrm{ml}$

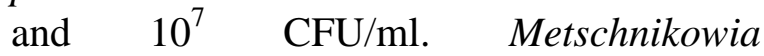
pulcherrima is assumed to use nutrients more than mold. The increase in the population of yeast can cause nutrient deficiencies. The deficiencies nutrient can result mold germination spore become obstructed.

In conclusion, two antagonistic yeasts were able to inhibit growth and sporulation of moulds, i.e. Aspergillus sp., and Penicillium sp. These yeast isolate with code T4.5.3.R and $\mathrm{T} 1.3 .5$ have potential as agent antagonisms which was in reducing mycelium growth with mechanism of nutrient competition and living space.

\section{Acknowledgement}

We express deep gratitude and appreciation to the Department Biology Universitas Negeri Jakarta Research Grant supported this research. We thank to the Lab. Microbiology and Universitas Negeri Jakarta Culture Collection (UNJCC) for the use of the facilities. For her valuable help for sampling thank to my student Saidah, Hilma, Adisa and Meillina.

\section{References}

Ahmad, R.Z. 2009. Cemaran kapang pada pakan dan pengendaliannya. $J$. Litbang Pertanian, 28(1): 15-22.

Ahmed, F., et al. 2008. Antibacterial, cytotoxic and neuropharmacological activities of Cerbera odollam seeds. Oriental Pharm. Experimental Med., 4: 323-328.

Cheenpracha, S., Karalai, C., Rat-A-Pa, Y., Ponglimanont, C., Chantrapomma, K. 2004. new cytotoxic cardenoline glycoside from the seeds of Cerberamanghas. Chem. Pham. Bull., 52: 1023-5.

D’Mello, J.P.F., Macdonald, A.M.C. 1998. Fungal toxins as disease elicitors. In J. Rose, ed. Environmental 
toxicology: current developments, pp. 253-289. Amsterdam, the Netherlands, Gordon and Breach Science Publishers.

Dufosse, L. 2006. Microbial production of food grade pigments. Food Technol. Biotechnol., 44: 313-321.

Druvefors, U.A. 2004. Yeast biocontrol of Grain Spoilage Moulds. Mode action of Pichia anomala. Thesis Swedish University of Agricultural Sciences, Uppsala: $44 \mathrm{hlm}$.

Fonseca, Á., Inácio, J. 2006. Phylloplane yeasts, pp. 263--301. Dalam: G. Peter, and $\mathrm{C}$. Rosa, The Yeast Handbook: Biodiversity and Ecophysiology of Yeasts. SpringerVerlag, Berlin Heidelberg. pp. 263405.

Gandjar, I., Sjamsuridzal, W., Oetari, A. 2006. Mikologi dasar dan terapan. Yayasan Obor Indonesia, Jakarta: xi $236 \mathrm{hlm}$.

Handayani, S., dan, J., Sulistyo. 2000. Analisis Keragaman Kapang Pencemar Pakan Unggas Komersial. Jurnal Mikrobiologi Indonesia, vol.5, Bogor: him. 36-38.

Kariba, R.M., et al. 2001. In vitro antifungal activity of Schizozygia coffaeoides Bail. (Apocynaceae) extracts. $J$. Ethnopharmacol., 74(1): 41-44.

Madigan, M.T., Martinko, J.M., Stahl, D.A., Clark, D.P. 2012. Brock biology of microorganisms. 13th ed. Pearson education, Inc., Boston, I-4 hlm.

Maruanovic, et al. 1991. Immunosuppressive effects of Fusarium moniliforme cultures in chickens. Poultry Sci., 70: 11951901.

Murniana, F.O., et al. 2011. Antifungal activity from seed of Cerbera odollam against Candida albicans. J. Natural, 11(1).
Labuda, R., Tančinová, D. 2006. Fungi recovered from Slovakian poultry feed mixtures and their toxinogenity. Annals Agri. Environ. Med., 13: 193-200.

Liu, P.C., Liu, M.H., Chen, S.Y., Cherng, W.J., Wang, C.H. 2008. Sea mango cardiac intoxication. Acta Cardiol Sin., 24: 9-56.

Sa'diyah, N.A., Purwani, K.I., Wijayawati, L. 2013. Pengaruh ekstrak daun bintaro (Cerbera odollam) terhadap perkembangan ulat grayak (Spodoptera litura). J. Sains dan Seni Pomits, 2(2): 2337-3520.

Spencer, J.F.T., Spencer, D.M. 1997. Ecology: Where yeasts live. Dalam: Spencer, J.F.T. \& D.M. Spencer. (eds). 1997. Yeasts in natural and artificial habitats. Springer, Berlin. pp. 33-67.

Sjamsuridzal, W. 2007. Yeast diversity and conservation Gunung Halimun National Park, Indonesia. Nagao Natural Environment Foundation, Depok: iii -254 hlm.

Sjamsuridzal, W., Oetari, A., Nakashima, C., Kanti, A., Saraswati, R., Widyastuti, Y., Ando, K. 2013. New species of genus Metschnikowia isolated from flowers in Indonesia, Metschnikowia cibodasensis sp. nov. J. Microbiol. Biotechnol., 23: 1-8.

Sukmawati, D., Oetari, A., Hendrayanti, D., Atria, M., Wellyzar Sjamsuridzal. 2015. Identification of phylloplane yeasts from paper mulberry (Broussonetia papyrifera (L.) L'Her.ex Vent.) in Java, Indonesia. $J$. Microbiol. Biotechnol. (Submitted).

Shareef, A.M. 2010. Molds and mycotoxins in poultry feeds from farms of potential mycotoxicosis. Iraqi J. Vet. Sci., Vol. 24, No. 1(17-25): 17.

Tabbu, C., Rangga. 2002. Penyakit Ayam dan Penanggulangannya 2. 
Kanisius. Yogyakarta.

Widiastuti, R., dan, R., Firmansyah. 2006. Cemaran zearalenon dan deoksinivalenol pada pakan sapi dan babi. Pros. Seminar Nasional Peternakan dan Veteriner. Bogor, Puslitbang Peternakan, Bogor. hIm.
968-971.

Utami, Sri. 2010. Aktivitas insektisida bintaro terhadap hama Eurema sp. Pada skala laboratorium. $J$. Penelitian Hutan Tanaman, 7(4): 211-220.

\section{How to cite this article:}

Dalia Sukmawati. 2016. Antagonism Mechanism of Fungal Contamination Animal Feed using Phylloplane Yeasts Isolated from the Bintaro Plant (Cerbera manghas) Bekasi in Java, Indonesia. Int.J.Curr.Microbiol.App.Sci. 5(5): 63-74.

doi: http://dx.doi.org/10.20546/ijcmas.2016.505.007 